\title{
The first case represented in Turkey; onychomycosis caused by Chaetomium globosum in an immunocompetent patient
}

\author{
Türkiye'de sunulan ilk vaka; immünokompetan hastada Chaetomium \\ globosum türünün etken olduğu tırnak onikomikozu
}

Fatma ÖZAKKAȘ ${ }^{1}$, Rabiye ALTINBAȘ ${ }^{1}$, Hafize SAV ${ }^{1}$, Mert Ahmet KUŞKUCU ${ }^{1}$, Kenan MidilLii', Nuri KIRAZ ${ }^{1}$

\begin{abstract}
It was reported as a case of distal subungual onychomycosis of the thumb of the right foot of a 25-year-old female patient in this article. Nail was examined in our laboratory and it was detected distal subungual onycomycosis. In direct microbiological examination septate hyphae was observed by using $20 \% \mathrm{KOH}$. Scraping of nail taken from patient was cultured on two Sabouraud's Dextrose Agar with cycloheximide and without cycloheximide and it was keept at $25{ }^{\circ} \mathrm{C}$ for one week. After growth of fungal was detected slide cultures were prepared and brown-colored septated hyphae, perithecia, lemon-shaped ascospores were observed by light microscopy. The causative agent was identified as Chaetomium globosum. It was determnied by using M38-A2 microdilution method, minimum inhibitory concentration values of, amphotericin B fluconazole, itracanozole, miconazole, ketoconazole, flucytosine voriconazole were determined as 4->64, 1-0.125, 0.125->64-0.5 $\mu \mathrm{g} / \mathrm{mL}$, respectively. Fluorocytosine and fluconazole were determined as resistant for Chaetomium globosum while miconazole and ketoconazole MIC values was determined as the best effective antifungal. The patient was treated
\end{abstract}

\section{ÖZET}

25yașında kadın hastanın sağ ayak bașparmağındaki distal subungual onikomikoz rapor olarak sunuldu. Tırnak muayenesi laboratuvarımızda yapıldı ve hastada distal subungual onikomikoz saptand. $\% 20 \mathrm{KOH}$ kullanılarak yapılan direkt mikroskobik incelemede; septalı hifler gözlemlendi. Hastadan alınan tırnak örnekleri siklohegzimitli ve siklohekzimitsiz Sabouraud's Dextrose Agara ekildi ve $25{ }^{\circ} \mathrm{C}$ 'de, bir hafta bekletildi. Fungal büyüme saptandıktan sonra direkt preparat hazırlandı, kahverengi septalı hifler, perithecia, limon benzeri askosporlar görüldü. Etken sekanslama ve konvansiyonel yöntemle Chaetomium globosum olarak tanımlandı. M38-A2 yöntemi kullanılarak amfotericin B, fluconazole, itraconazole, miconazole, ketoconazole, flucytosine voriconazole MiK değerleri sırasıyala 4->64, 1-0, 125, 0,125->64, 0,5 $\mu \mathrm{g} / \mathrm{mL}$ olarak belirlendi. Chaetomium globosum için fluorocytosine ve fluconazole dirençli olarak saptanırken miconazole ve ketoconazole MiK değerleri en etkili olarak saptandı. Hasta günlük (250 $\mathrm{mg} /$ gün) oral itraconazole ve amorolfin \%5 tırnak cilası kullandı ve 12 haftada iyileșme kayıt edildi.

Anahtar Kelimeler: chaetomium, onikomikoz,

'Istanbul University, Cerrahpasa Medical Faculty, Department of Microbiology, Istanbul 
by using oral itraconazole daily ( $250 \mathrm{mg} / \mathrm{a}$ day) and local application of amorolfine $5 \%$ nail lacquer was used and it was seen to heal in 12 weeks.

Key Words : chaetomium, onychomycosis, antifungal susceptibiltiy antifungal duyarılık 


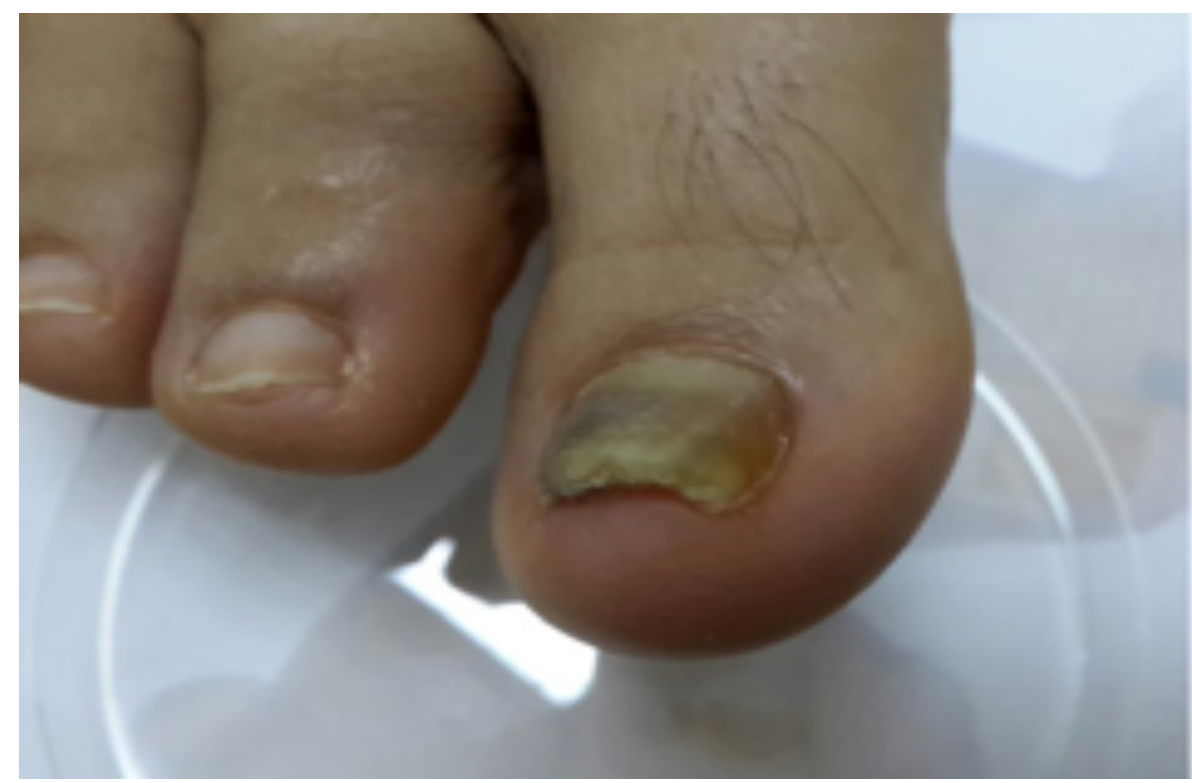

Figure 1. Distal subungal onycomycosis and brownish-yellow discoloration on the right toenails.

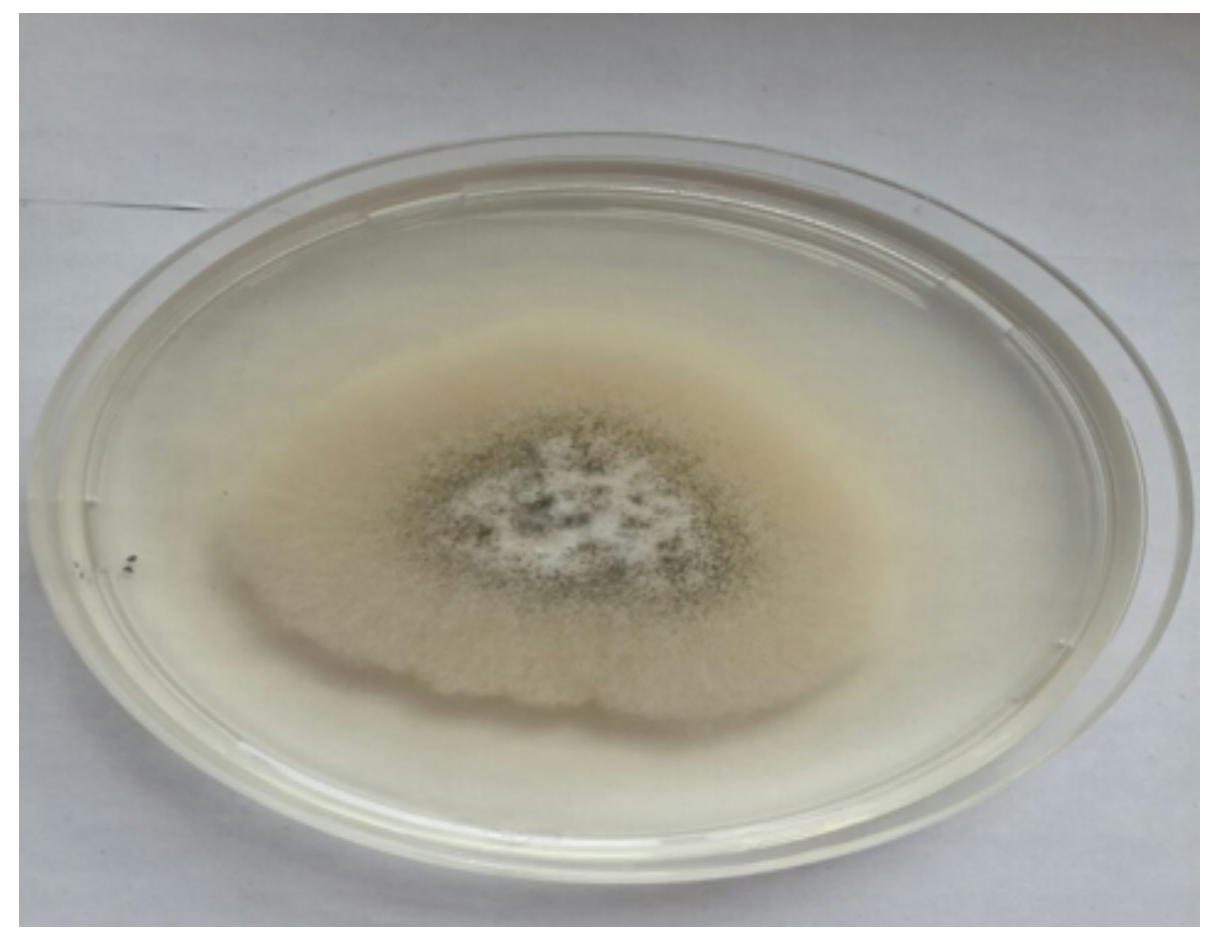

Figure 2. Dark gray to brown colony on Sabourauds Dextrose Agar. 


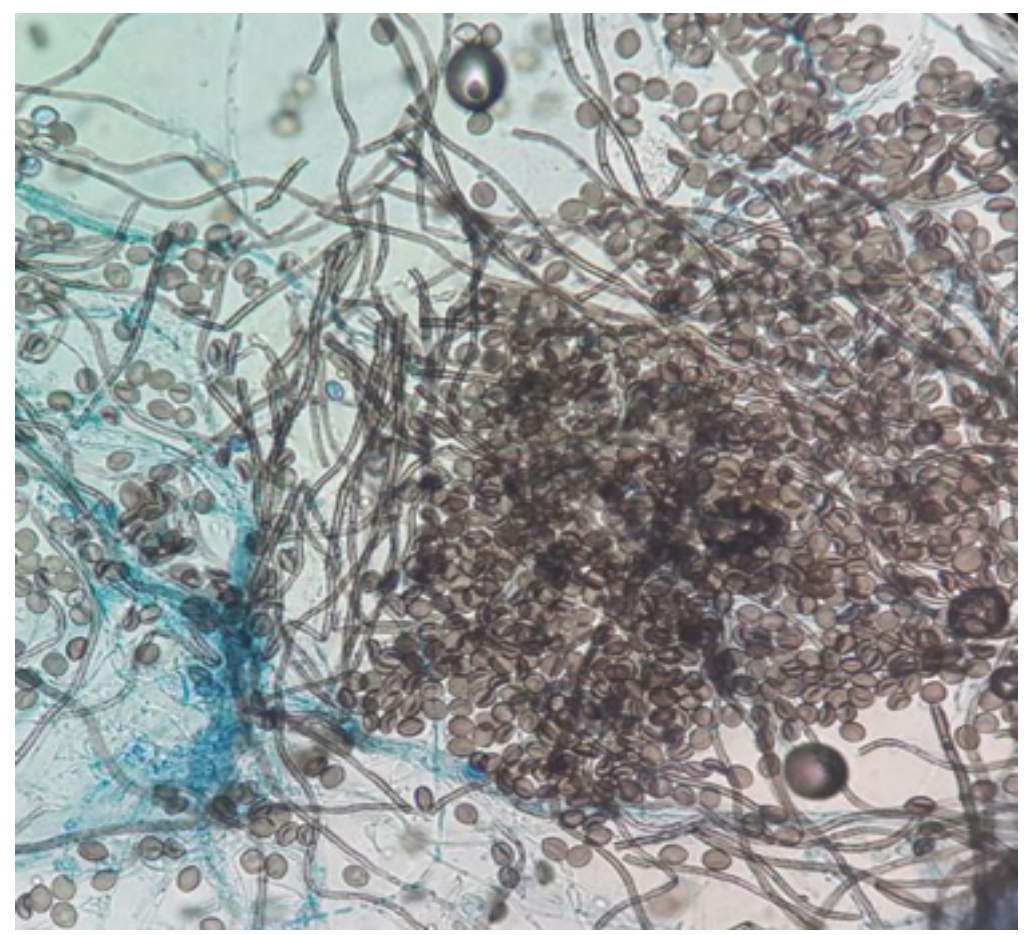

Figure 3. Brown-colored septated hyphae and, lemon shaped ascospores.

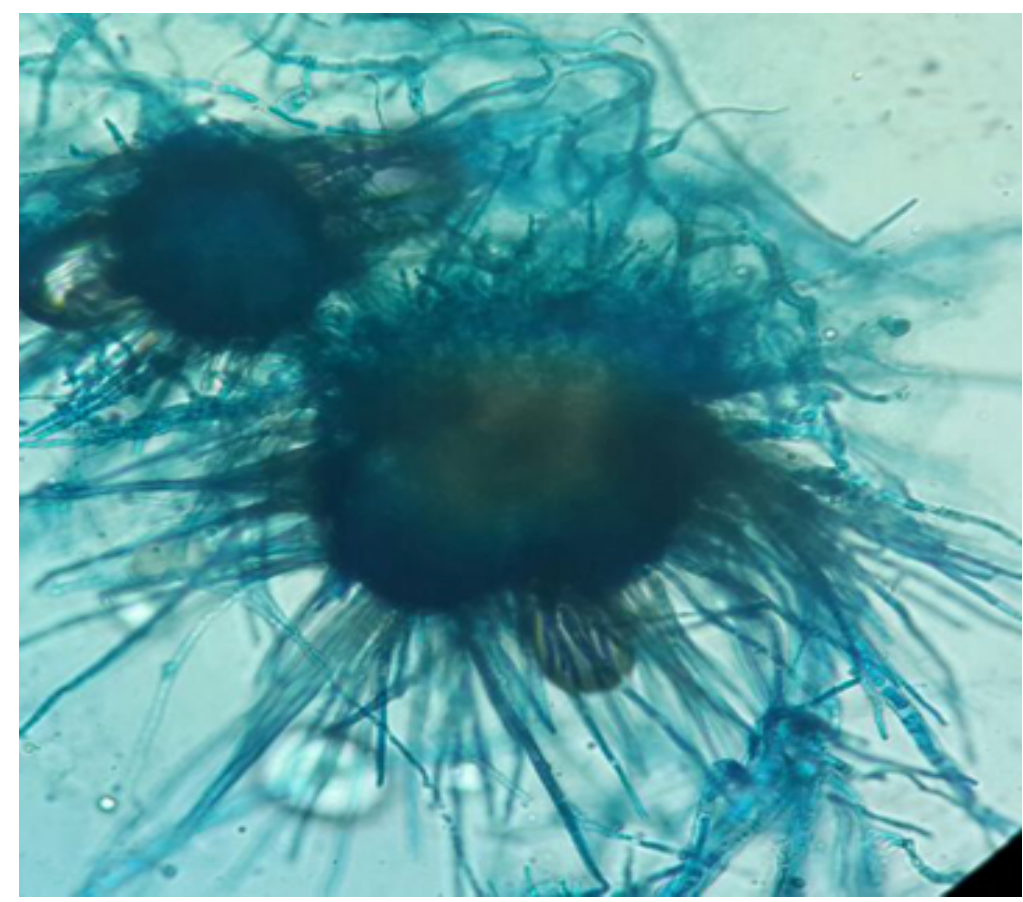

Figure 4. Dark brown to black, flask-shaped perithecia. 
DNA Extraction, PCR Amplification, and Analysis of the ITS Region

Fungal DNA is amplified by using universal fungal primers (ITS1 and ITS4) by PCR described elsewhere (10). Positive PCR band is purified and sequenced bidirectionally. Obtained DNA sequences are edited, aligned and a consensus sequence is constructed. BLAST search is performed with obtained consensus sequence and maximum similarity is founded with Chaetomium globosum.

\section{Antifungal Susceptibility Testing}

Reference broth microdilution method performed according to M38-A2 document (11). Pure antifungal powders of known potency were supplied by the respective manufacturing companies (fluconazole, voriconazole (Pfizer, Istanbul, Turkey); amphotericin B, miconazole, flucytosine, ketoconazole, itracanozole (Sigma-Aldrich, St. Louis, Missouri, USA)). RPMI 1640 Medium (Sigma) with 0.2\% glucose L-glutamine and without bicarbonate was employed. The inoculum was prepared by overlaying mature slants with sterile distilled water and gently scraping the surface with a wooden applicator stick. The suspension was permitted to sit for five minutes to allow large particles to settle out. Inocula of $C$. globosum were prepared with a hemocytometer. The minimum inhibitory concentrations (MICs) were read at $72 \mathrm{~h}$. The final inocula were adjusted as $0.34 \times$ $10^{4}$ to $6.5 \times 10^{4}$ spores $/ \mathrm{mL}$ in the microtiter plates. MIC values were determined for amphotericin B $(4 \mu \mathrm{g} /$ $\mathrm{mL})$, fluconazole $(>64 \mu \mathrm{g} / \mathrm{mL})$, itracanozole $(1 \mu \mathrm{g} / \mathrm{mL})$, miconazole $(0.125 \mu \mathrm{g} / \mathrm{L})$, ketoconazole $(0.125 \mu \mathrm{g} /$ $\mathrm{mL})$, flucytosine $(>64 \mu \mathrm{g} / \mathrm{mL})$, voriconazole $(0.5 \mu \mathrm{g} /$ $\mathrm{mL}$ ). The most effective antifugal agents were found as miconazole $(0.125 \mu \mathrm{g} / \mathrm{mL})$ and ketoconazole $(0.125 \mu \mathrm{g} / \mathrm{mL})$. The patient was treated by using oral itraconazole ( $250 \mathrm{mg} / \mathrm{a}$ day) and local application of amorolfine $5 \%$ nail lacquer was used and it was seen to heal in 12 weeks.

\section{DISCUSSION}

In this report we discussed mycological examination and antifungal treatment of onycomycosis stemming from $C$. globosum. These species produce chaetoglobosins $\mathrm{A}$ and $\mathrm{C}$ and mycotoxin exposure may be associated with cutaneous, subcutaneous, and opportunistic fungal infection (7). Until today, author reported a small number of onycomycosis caused by $C$. globosum in adult patients (12-16). Among these cases only one mixed toenail infection caused by C. Globosum and Trichophyton mentagrophytes was reported (17). In all cases, male patients were found to be more affected than female patients. In this case, onycomycosis occured in a female patients toenail.

Clinical presentation of onychomycosis resulting from C. globosum is often nonspecific. Since this fungi is believed as common laboratory contaminants, it is difficult to recognize between the pathogen and the contaminant. If their characteristic images are seen in microscopic examination and the same strain is identified on repeated cultures, they can be considered as a pathogen of onychomycosis. In addition to phenotypic identification, DNA sequence analysis is useful in corroborating the diagnosis in difficult cases of onychomycosis (13). In our case, more or less flask-shaped, mostly ostiolate (perithecia) fruit body, ascospores and hyphae were seen in microscopic examination and fungal growth was observed in three different cultures. Mycological examination and DNA sequence analysis were used for C. globosum identification. For molecular biologic analysis, it was compared to the base sequence of C. globosum strain KM579606, which was stored in GenBank, using the Blast program and the result was $100 \%$ matched (Figure 5). 
PITS1-4

ATTGTGACGTTACCTATACCGTTGCTTCGGCGGGCGGCCCCGGGGTTTACCCCCC GGGCGCCCCTGGGCCCCACCGCGGGCGCCCGCCGGAGGTCACCAAACTCTTGATA ATTTATGGCCTCTCTGAGTCTTCTGTACTGAATAAGTCAAAACTTTCAACAACGGA TCTCTTGGTTCTGGCATCGATGAAGAACGCAGCGAAATGCGATAAGTAATGTGAA TTGCAGAATTCAGTGAATCATCGAATCTTTGAACGCACATTGCGCCCGCCAGCAT TCTGGCGGGCATGCCTGTTCGAGCGTCATTTCAACCATCAAGCCCCCGGGCTTGT GTTGGGGACCTGCGGCTGCCGCAGGCCCTGAAAAGCAGTGGCGGGCTCGCTGTC GCACCGAGCGTAGTAGCATACATCTCGCTCTGGTCGCGCCGCGGGTTCCGGCCGT TAAACCACCTTTT

Figure 5. Sequences producing significant aligments.

Onycomycosis is clasified as different clinical types for etiological agent and treatment (18). In this case, clinical form was detected as distal subungual onycomycosis. We observed brownish discoloration without periungual inflammation in dermatological examination.

Eradication of onycomycosis caused by non dermatophyte mold is diffucult and time consuming. Because these molds don't respond well to antifungal treatment and antifungal susceptibility of these species is not well established.Our information about the antifungal susceptibilityof Chaetomium is limited. Serena et al., (9) investigated antifungal susceptibilities of Chaetomium and they reported that in vitro activities of ravuconazole, voriconazole, albaconazole were obtained as good, but micafungin was not. Guarro et al., (19) tested the activities of six antifungal agents against clinical and environmental strains of Chaetomium spp. fluorocytosine and fluconazole were determined as resistant for all strains and the best effective antifungal was determined as itraconazole. Similarly, in our study
MIC values of fluorocytosine and fluconazole were found as resistant. The best fungal activities were determined as miconazole $(0.125 \mu \mathrm{g} / \mathrm{mL})$ and ketoconazole $(0.125 \mu \mathrm{g} / \mathrm{mL})$.

In literature, successful treatment was reported by using itraconazole and terbinafine $(13,16)$. The Food and Drug administration (FDA) approve treatment regimen for toenails is itraconazole $200 \mathrm{mg}$ per day for 3 month (20). Itraconazole MIC value was determined as $(1 \mu \mathrm{g} / \mathrm{mL})$ in our antifungal susceptibility study. Clinician administerid oral itraconazole (250 mg /a day ) and local application of amorolfine $5 \%$ nail lacquer. As a result, the patient was completely cured as clinically and mycologically.

In conclusion, we report the onychomycosis caused by $C$. globosum in an immunocompetent patient which was confirmed by mycological examination and molecular analysis. Antifungal susceptibility was performed and the most effective agent was determined as ketoconazole and miconazole, but clinical recovery was provided by using itraconazole. 


\section{ACKNOWLEDGEMENTS}

Case was presented as poster at 7 th Trends in Medical Mycology Congress, Lisbon-Portugal, 9-12 October, 2015.

\section{KAYNAKLAR}

1. Fernández MS, Rojas FD, Cattana ME, Sosa Mde L, Mangiaterra ML, Giusiano GE. Aspergillus terreus complex: an emergent opportunistic agent of Onychomycosis. Mycoses,2013; 56 (4): 477-81.

2. Hwang SM, Suh MK, Ha GY. Onychomycosis due to nondermatophytic molds. Ann Dermatol ,2012; 24 (2): $175-80$.

3. Cuomo CA, Untereiner WA, Li-Jun Ma, Grabherr $M$, Birren BW. Draft genome sequence of the cellulolytic fungus Chaetomium globosum. Genome Announc, 2015; 26; 3(1): pii:e00021-15.

4. Udagawa S, Muroi T, Kurata H, Sekita S, Yoshihira K, Natori S, et al. The production of chaetoglobosins, sterigmatocystin, omethylsterigmatocystin, and chaetocin by Chaetomium spp. and related fungi. Can J Microbiol, 1979; 25 (2): 170-7.

5. Kane J, Summerbell R, Sigler L, Krajden S, Land J. Laboratory Handbook of Dermatophytes. 9th, USA: Star Publishing Company, 1997.

6. Samson RA, Houbraken J, Thrane U, Frisvad JC, Andersen B. Food and Indoor Fungi. Netherlands: CBS-KNAW Fungal Biodiversity Centre, 2010.

7. Nielsen KF, Gravesen S, Nielsen PA, Andersen B, Thrane U, Frisvad JC. Production of mycotoxins on artificially and naturally infested building materials. Mycopathologia, 1999;145(1):43-56.

8. de Hoog GS, Guarro J, Figueras MJ. Atlas of Clinical Fungi: The Ultimate Benchtool for Diagnostics. 4th. Netherlands: CBS-KNAW Fungal Biodiversity Centre, 2015.
9. Serena C, Ortoneda M, Capilla J, Pastor FJ, Sutton DA, Rinaldi MG, et al. In vitro activities of new antifungal agents against Chaetomium spp. and inoculum standardization. Antimicrob Agents Chemother, 2003; 47 (10): 3161-4.

10. Lindsley MD, Hurst SF, lqbal NJ, Morrison CJ. Rapid identification of dimorphic and yeast-like fungal pathogens using specific DNA probes. J Clin Microbiol, 2001; 39 (10): 3505-11.

11. Anonymous. Clinical and Laboratory Standards Institute. Reference Method for Broth Dilution Antifungal Susceptibility Testing of Filamentous Fungi. CLSI Document M38-A2. USA: Clinical and Laboratory Standards Institute, Wayne, PA, 2008.

12. Falcón CS, Falcón Ma del Mar S, Ceballos JD, Florencio VD, Erchiga VC, Ortega SS. Onychomycosis by Chaetomium spp. Mycoses, 2009; 52 (1): 77-9.

13. Kim DM, Lee MH, Suh MK, Ha GY, Kim H, Choi JS. Onychomycosis caused by Chaetomium globosum. Ann Dermatol, 2013; 25 (2): 232-6.

14. Aspiroz C, Gené J, Rezusta A, Charlez L, Summerbell RC. First Spanish case of onychomycosis caused by Chaetomium globosum. Med Mycol, 2007; 45 (3): 279-82.

15. Stiller MJ, Rosenthal S, Summerbell RC, Pollack J, Chan A Onychomycosis of the toenails caused by Chaetomium globosum. J Am Acad Dermatol, 1992; 26 (5 Pt 1): 775-6.

16. Hattori $N$, Adachi $M$, Kaneko $T$, Shimozuma $M$, Ichinohe M, lozumi K. Case report. Onychomycosis due to Chaetomium globosum successfully treated with itraconazole. Mycoses, 2000; 43(1-2): 89-92. 
17. Lagacé J, Cellier E. A case report of a mixed Chaetomium globosum/trichophyton mentagrophytes onychomycosis. Med Mycol Case Rep, 2012; 16; 1(1): 76-8.

18. Hay RJ, Baran R. Onychomycosis: a proposed revision of the clinical classification. J Am Acad Dermatol, 2011; 65 (6): 1219-27.
19. Guarro J, Soler L, Rinaldi MG. Pathogenicity and antifungal susceptibility of Chaetomium species. Eur J Clin Microbiol Infect Dis, 1995;14 (7): 613-8.

20. Finch JJ, Warshaw EM. Toenail onychomycosis: current and future treatment options. Dermatol Ther, 2007; 20 (1): 31-46. 